\title{
In vitro and in vivo effect of verapamil on human airway responsiveness to leukotriene $\mathrm{D}_{4}$
}

\author{
JA ROBERTS, MA GIEMBYCZ, D RAEBURN, IW RODGER, NC THOMSON
} From the Department of Respiratory Medicine, Western Infirmary, and the Department of Physiology and
Pharmacology, University of Strathclyde, Glasgow

ABSTRACT The mechanism by which leukotriene $\mathrm{D}_{4}\left(\mathrm{LTD}_{4}\right)$ induces airway narrowing in man is unclear. We have investigated this by examining the effect of the calcium channel blocker verapamil on the sensitivity of in vitro preparations of human bronchi to $\mathrm{LTD}_{4}$ and methacholine, and on the bronchoconstriction induced in normal subjects by these agonists in vivo. In vitro smooth muscle sensitivity was assessed by the concentration of $\mathrm{LTD}_{4}$ and methacholine causing a $50 \%$ of maximum contraction $\left(\mathrm{EC}_{50}\right)$ and as the maximum tension generated. Verapamil did not alter baseline tension or the response to $\mathrm{LTD}_{4}$ but did inhibit contractile responses to methacholine. In vivo studies were performed in six normal subjects; they inhaled increasing concentrations of $\mathrm{LTD}_{4}$ $(0.4-50 \mu \mathrm{g} / \mathrm{ml})$ or methacholine $(2-64 \mathrm{mg} / \mathrm{ml})$. Airway responsiveness in vivo was expressed as the provocation concentration (PC) of agonist producing a $35 \%$ fall in specific airways conductance $\left(\mathrm{PC}_{35} \mathrm{sGaw}\right)$ and a $30 \%$ fall in flow at $30 \%$ of vital capacity $\left(\mathrm{PC}_{30} \dot{\mathrm{V}}_{30}(\mathrm{p})\right)$. Verapamil did not alter baseline sGaw or $\dot{\mathrm{V}}_{30}(\mathrm{p})$. One subject did not respond to $\mathrm{LTD}_{4}$ on either day. In contrast to the in vitro results, verapamil produced a greater than 10 fold reduction in LTD $_{4}$ induced bronchoconstriction, but had no effect on methacholine induced bronchoconstriction. These results suggest that in normal subjects bronchoconstriction induced by inhaled $\mathrm{LTD}_{4}$ is due to a combination of direct and indirect mechanisms.

Leukotriene $\mathrm{D}_{4}\left(\mathrm{LTD}_{4}\right)$ is a potent bronchoconstrictor in man and may be an important mediator in asthma. ${ }^{1-3}$ Specific binding sites (receptors) for leukotrienes have been identified in the lungs of different species, including man. ${ }^{45}$ Although in vitro contractile responses of airway smooth muscle from these species have been shown to be receptor mediated, the mechanism or mechanisms underlying leukotriene induced bronchoconstriction in man in vivo is uncertain. Since contraction of airway smooth muscle is dependent on calcium ion influx ${ }^{67}$ we have examined the effects of the calcium channel blocking drug verapamil on the airway response to inhaled LTD $_{4}$ in a group of normal subjects. We also examined the effects of verapamil on the in vitro LTD $_{4}$ concentration-response curve for human bronchial smooth muscle.

\section{Methods}

IN VITRO STUDY

Bronchial tissue was obtained rapidly from lung

Address for reprint requests: Dr JA Roberts, Department of Respiratory Medicine, Western Infirmary, Glasgow G11 6NT.

Accepted 8 July 1985 removed from patients undergoing lung resection for bronchial carcinoma. Samples from second to sixth order bronchi were dissected from areas of macroscopically normal tissue and maintained at $4^{\circ} \mathrm{C}$ overnight in oxygenated Krebs-Henseleit physiological salt solution of the following composition: $\mathrm{NaCl} 118$; $\mathrm{KCl} 4.7 ; \mathrm{MgSO}_{4} \quad 1.2 ; \mathrm{KH}_{2} \mathrm{PO}_{4} \quad 1.2 ; \mathrm{CaCl}_{2} 2.5$; $\mathrm{NaHCO}_{3} 25$; and glucose $11.7 \mathrm{mmol} / \mathrm{l}$. On the following day bronchi were dissected free of extraneous connective tissue and sectioned to produce transverse strips of tissue. These were suspended, under a resting tension of 1.5 to $2.0 \mathrm{~g}$, in a $5 \mathrm{ml}$ organ bath containing Krebs-Henseleit solution at $37^{\circ} \mathrm{C}$ bubbled with $5 \%$ carbon dioxide in oxygen. During a 60 minute equi- ? libration period the tissues were washed three times. N Changes in isometric tension were measured with $N$ force-displacement transducers (Grass, FTO3C) and recorded on an ink writing polygraph (Grass, model 7).

The reproducibility of the contractile changes of the bronchial strips was assessed by adding methacholine $\left(1 \times 10^{-4} \mathrm{~mol} / \mathrm{l}\right)$ on two occasions with an interval of 30 minutes for recovery after each drug $\underset{\mathbb{D}}{\stackrel{D}{ }}$ had been added. A cumulative concentration-effect $\stackrel{\stackrel{\sim}{\mathbb{D}}}{\mathrm{O}}$ curve for $\mathrm{LTD}_{4}$ or methacholine was then constructed by adding increasing concentrations of the drug, 
Effect of verapamil on baseline lung function

\begin{tabular}{|c|c|c|c|c|c|c|c|c|}
\hline & \multicolumn{4}{|c|}{ Leukotriene $D_{4}(n=5)$} & \multicolumn{4}{|c|}{ Methacholine $(n=6)$} \\
\hline & \multicolumn{2}{|c|}{$\operatorname{sGaw}\left(s^{-1} k P a^{-1}\right)$} & \multicolumn{2}{|c|}{$\dot{V}_{30}(p)\left(l s^{-1}\right)$} & \multicolumn{2}{|c|}{$s G a w\left(s^{-1} k P a^{-1}\right)$} & \multicolumn{2}{|c|}{$\dot{V}_{30}(p)\left(l s^{-1}\right)$} \\
\hline & Baseline & After treatment & Baseline & After treatment & Baseline & After treatment & Baseline & After treatment \\
\hline $\begin{array}{l}\text { Verapamil } \\
\text { Control } \\
\text { p value }\end{array}$ & $\begin{array}{l}1.59(0.17) \\
1.88(0.29)\end{array}$ & $\begin{array}{l}1.78(0.28) \\
2.12(0.15) \\
\text { NS }\end{array}$ & $\begin{array}{l}1.92(0.27) \\
1.82(0.23)\end{array}$ & $\begin{array}{l}1.93(0.25) \\
1.85(0.23) \\
\text { NS }\end{array}$ & $\begin{array}{l}2.00(0.25) \\
2.02(0.27)\end{array}$ & $\begin{array}{l}2.14(0.28) \\
2.11(0.40) \\
\text { NS }\end{array}$ & $\begin{array}{l}1.82(0.16) \\
1.82(0.22)\end{array}$ & $\begin{array}{l}1.82(0.16) \\
1.77(0.22) \\
\text { NS }\end{array}$ \\
\hline
\end{tabular}

sGaw-specific airways conductance.

$\dot{\mathrm{V}}_{30}(\mathrm{p})$-partial expiratory flow rate measured at $30 \%$ of vital capacity.

each addition of the drug being made at the peak of the response produced by the preceding concentration. After washout of the agonist and full recovery to control resting tension, either verapamil $(1 \times$ $\left.10^{-6} \mathrm{~mol} / \mathrm{l}\right)$ or vehicle was added to the bath. Thirty minutes later a second concentration-effect curve was constructed. The concentration of $\mathrm{LTD}_{4}$ and methacholine that produced a $50 \%\left(\mathrm{EC}_{50}\right)$ of maximum contraction was calculated from the graphically displayed data. In each experiment four to six bronchial strips from each patient were examined. For each bronchial strip the responses to $\mathrm{LTD}_{4}$ and methacholine elicited in the presence of verapamil were calculated as a percentage of that produced in the absence of the calcium channel blocking drug.

\section{IN VIVO STUDY}

We studied six normal subjects aged 22-36 years, five of them male. All were non-smokers and gave no history of respiratory disease and none was taking any drug treatment. The mean forced expiratory volume in one second $\left(\mathrm{FEV}_{1}\right)$, was $97.5 \%$ (SE $2.2 \%$ ) of the predicted value. All subjects gave informed consent and the experimental protocol was approved by the Western Infirmary ethical committee.

Airways resistance (Raw) and thoracic gas volume (TGV) were measured in a constant volume body plethysmograph (Fenyves and Gut), and we used a computerised data collection and analysis system based on the method of DuBois et al. ${ }^{8}$ The results were expressed as specific airways conductance (sGaw) $\left(=\frac{1}{\operatorname{Raw}} \times \frac{1}{\mathrm{TGV}}\right)$. The mean of eight values measured was taken as sGaw. Flow-volume curves were constructed as follows. After a period of normal tidal breathing, the subject expired maximally from end tidal inspiratory volume to residual volume (RV) to obtain the partial expiratory flow-volume (PEFV) curve. When RV was reached, the subject inspired to total lung capacity (TLC) and then expired maximally to RV. From this manoeuvre $\mathrm{FEV}_{1}$ and maximum expiratory flow at $70 \%$ of expired vital capacity, obtained from the partial flow-volume $\left(\mathrm{V}_{30}(\mathrm{p})\right)$ curve, were measured automatically (Collingwood
Measurement). Measurements in the body plethysmograph measurements always preceded flowvolume recordings. Aerosols were generated with a Wright nebuliser by air at $50 \mathrm{lb} / \mathrm{in}^{2}(345 \mathrm{kPa})$ at a flow rate of $81 \mathrm{~min}^{-1}$ to achieve an output of $0.15 \mathrm{ml}$ $\min ^{-1}$.

Each subject received either inhaled verapamil (2.5 $\mathrm{mg} / \mathrm{ml}$ ) or normal saline in a randomised single blind manner on four separate days. After baseline measurements of sGaw (mean of eight readings) and $\dot{\mathrm{V}}_{30}$ (p) (mean of five readings) the solutions were inhaled for five minutes. After 15 minutes lung function tests were repeated. Leukotriene $\mathrm{D}_{4}$ and methacholine inhalation tests were carried out with a modification of our previously described method. ${ }^{910}$ Buffered saline was inhaled first, followed by increasing concentrations of $\mathrm{LTD}_{4}(0.4-50 \mu \mathrm{g} / \mathrm{ml})$ or methacholine $(2-64 \mathrm{mg} / \mathrm{ml})$. Each concentration was inhaled for two minutes. Inhalations were repeated every 15 minutes for LTD $_{4}$ and every 10 minutes for methacholine. Two $\mathrm{LTD}_{4}$ and two methacholine inhalation tests were performed on each subject after verapamil and saline respectively. Results were expressed as the provocation concentration (PC) producing a $35 \%$ fall in sGaw ( $\mathrm{PC}_{35} \mathrm{sGaw}$ ) and a $30 \%$ fall in $\dot{\mathrm{V}}_{30}(\mathrm{p})$. Results were compared by analysis of variance and Student's $t$ test.

\section{Results}

IN VITRO STUDY

$\operatorname{LTD}_{4}\left(1 \times 10^{-10}\right.$ to $\left.2 \times 10^{-7}\right)$ and methacholine $(1$ $\times 10^{-9}$ to $1 \times 10^{-3}$ ) mol $1^{-1}$ elicited concentration dependent contractions of the bronchial strip preparations (fig 1). There was no significant difference in the sensitivities to $\mathrm{LTD}_{4}$ or methacholine of bronchial strips prepared from the same patient. Mean (SE) $\mathrm{EC}_{50}$ values from all experiments were $2.6(0.8)$ $\times 10^{-8} \mathrm{~mol} / \mathrm{l}(\mathrm{n}=7)$ for $\mathrm{LTD}_{4}$ and $1.7(0.3) \times 10^{-6}$ $\mathrm{mol} / \mathrm{l}(\mathrm{n}=18)$ for methacholine. Contractions to $\mathrm{LTD}_{4}$ were slow to develop, taking 12 (4) minutes to achieve peak effect from each concentration of drug used. The mean maximum contraction elicited by $\mathrm{LTD}_{4}$ at the highest concentration tested was 17 (3) 

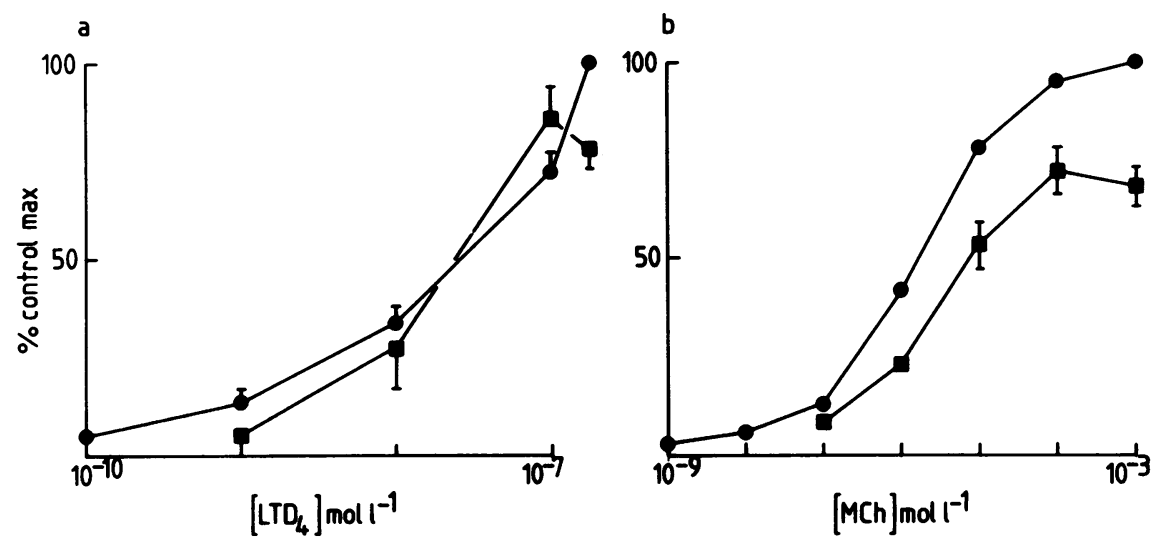

Fig 1 Effects of verapamil $\left(1 \times 10^{-6} \mathrm{~mol} / \mathrm{l}\right)$ on $(\mathrm{a})$ leukotriene $\mathrm{D}_{4}\left(\mathrm{LTD}_{4}\right)$ and $(\mathrm{b})$ methacholine (MCh) induced contractions of human isolated bronchial preparations. Each point represents the mean (as percentage of control) maximum response from seven (panel a) and 18 (panel b) separate experiments before (O) and after ( $\square$ ) verapamil. Standard errors of the mean are shown by vertical bars.

$\mathrm{mN}$, though it was not normally possible to test concentrations in excess of $2 \times 10^{-7} \mathrm{~mol} / \mathrm{l}$ because of the limited supply of the eicosanoid. This was not significantly different from the maximum contraction produced by methacholine $(18(2) \mathrm{mN})$. On the two occasions when $\mathrm{LTD}_{4}$ could be tested at a higher concentration $\left(4 \times 10^{-7} \mathrm{~mol} / \mathrm{l}\right)$ the resulting contraction was no greater than that elicited by $2 \times 10^{-7} \mathrm{~mol} / \mathrm{l}$ ). $\mathrm{LTD}_{4}$ induced contractions were slowly reversed, requiring 60-80 minutes to return to baseline tension levels with repeated washing of the tissue with fresh physiological salt solution. In a few experiments a second cumulative concentration-effect curve for LTD $_{4}$ was constructed after an interval of about 120 minutes. There were no significant differences between the two curves-indeed, they could be virtually superimposed on each other.

Verapamil $\left(1 \times 10^{-6} \mathrm{~mol} / \mathrm{l}\right)$ had no effect on baseline tension during the 30 minutes equilibration period. It was without significant effect on the major portion of the LTD $_{4}$ concentration-effect curve, although a slight inhibition of response was observed at the highest concentration of $\mathrm{LTD}_{4}$ used (fig $1 a$ ). The same concentration of verapamil inhibited all contractile responses to methacholine and depressed the maximum contraction by $29 \%(5 \%)$ (fig $1 b$ ).

\section{IN VIVO STUDY}

Inhalation of verapamil did not alter baseline sGaw or $\dot{\mathrm{V}}_{30}(\mathrm{p})$ (table). One subject failed to respond to $\mathrm{LTD}_{4}$ on either day. In the other five subjects verapamil significantly inhibited $\mathrm{LTD}_{4}$ induced bronchoconstriction (fig $2 a$ ). The geometric mean PC values underestimate the effect of verapamil on LTD induced bronchoconstriction since three subjects did not develop bronchoconstriction in response to the highest concentration of $\mathrm{LTD}_{4}$ administered. These subjects were assigned the highest concentration of $\mathrm{LTD}_{4}(50 \mu \mathrm{g} / \mathrm{ml})$ as their PC value to allow statistical analysis. $\mathrm{PC}_{35}$ sGaw LTD $\mathrm{LT}_{4}$ increased from 1.64 (0.62) $\mu \mathrm{g} / \mathrm{ml}$ (geometric mean (SE)) after placebo to 20.11 (1.11) $\mu \mathrm{g} / \mathrm{ml}$ after verapamil $(\mathrm{p}<0.01)$. $\mathrm{PC}_{30} \dot{\mathrm{V}}_{30}(\mathrm{p})$ $\mathrm{LTD}_{4}$ increased from $1.87(3.17) \mu \mathrm{g} / \mathrm{ml}$ after placebo to $20.46(1.57) \mu \mathrm{g} / \mathrm{ml}$ after verapamil $(\mathrm{p}<0.01)$. All six subjects developed chest tightness but none coughed after $\mathrm{LTD}_{4}$.

Verapamil had no effect on responsiveness to methacholine (fig $2 \mathrm{~b}$ ). $\mathrm{PC}_{35}$ sGaw methacholine was $8.67(2.78) \mu \mathrm{g} / \mathrm{ml}$ after placebo and $6.81(3.6) \mu \mathrm{g} / \mathrm{ml}$ after verapamil (not significant). $\mathrm{PC}_{30} \dot{\mathrm{V}}_{30}(\mathrm{p})$ methacholine was $6.98(3.60) \mathrm{mg} / \mathrm{ml}$ after placebo and 6.77 $(1.59) \mathrm{mg} / \mathrm{ml}$ after verapamil (not significant).

\section{Discussion}

Inhaled verapamil inhibited LTD $_{4}$ but not methacholine induced bronchoconstriction in normal subjects. In contrast, verapamil had no inhibitory effect on the response of human airway smooth muscle 0 strips to $\mathrm{LTD}_{4}$ and only a small, though significant, $\overparen{\varnothing}$ inhibitory effect on the response to methacholine.

LTD $_{4}$ and methacholine elicited concentration dependent contraction of isolated bronchial smooth muscle. In the case of methacholine these effects were clearly mediated via stimulation of muscarinic receptors since the responses were competitively inhibited 
LTD
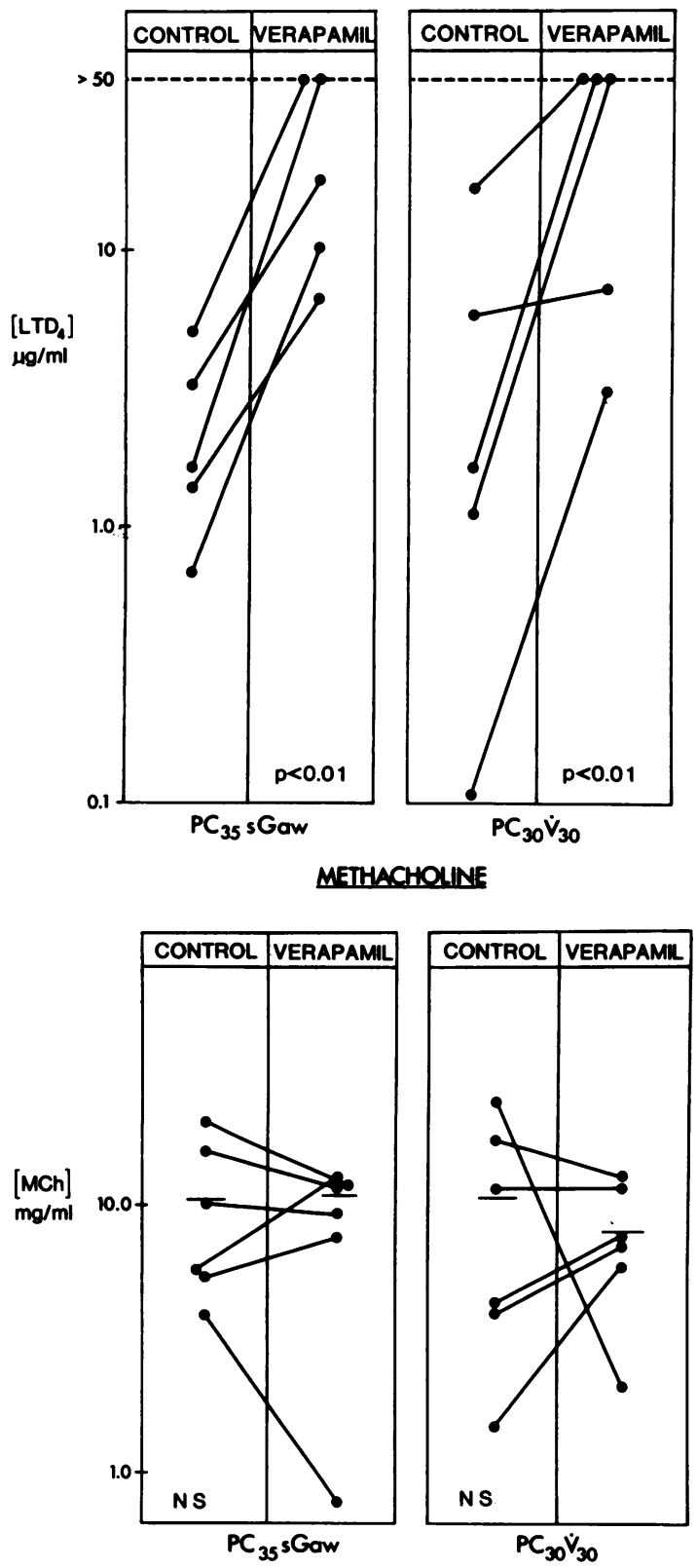

Fig 2 Effect of pretreatment with verapamil $(2.5 \mathrm{mg} / \mathrm{ml})$ or control (buffered saline) inhalations on airway responsiveness to (a) leukotriene ( $\mathrm{LTD}_{4}$ ) and (b) methacholine (MCh). Results are expressed as the provocation concentration (PC) producing a decrease in $s$ Gaw of $35 \%\left(P C_{35}\right.$ sGaw) and $a$ decrease in $\dot{V}_{30}(p)$ of $30 \%\left(P C_{30} \dot{V}_{30}(p)\right.$. Verapamil significantly reduced the response to $L T D_{4}(p<0.01)$ but not to methacholine. by atropine (unpublished observations). In the absence of a suitable selective antagonist competing for $\mathrm{LTD}_{4}$ receptors a similar experiment was not feasible with LTD $_{4}$. As in a previous study, ${ }^{11}$ however, contractions elicited by $\mathrm{LTD}_{4}$ were unaffected by mepyramine or atropine or by inhibition of the cyclooxygenase pathway with flurbiprofen (unpublished observations), in keeping with a previous report. ${ }^{11}$ These results would tend to exclude an indirect effect of $\mathrm{LTD}_{4}$ mediated via histamine released from mast cells, acetylcholine released from vagal nerve terminals, constrictor cyclo-oxygenase products such as thromboxane $A_{2}$ or the constrictor prostaglandins $\mathrm{PGF}_{2 \alpha}$ and $\mathrm{PGD}_{2}$. Thus the observed effects of $\mathrm{LTD}_{4}$ in vitro are likely to be receptor mediated.

The in vitro studies were performed on tissue from patients who were older than the subjects tested in vivo, so an effect of age cannot be excluded. The preoperative and perioperative drugs received by the surgical patients are unlikely to have influenced in vitro responsiveness since all tissues were washed on several occasions and stored overnight in physiological saline before testing. ${ }^{910}$

Contraction of airway smooth muscle is dependent on an increase in the concentration of calcium ions $\left(\mathrm{Ca}^{2+}\right)$ within the myoplasm of the cell. ${ }^{6712}$ These so called activator calcium ions may be supplied from the extracellular fluid surrounding the cell or from storage sites such as the sarcoplasmic reticulum, within the cell. ${ }^{6712}$ Contraction of guinea pig airway smooth muscle by agonists is highly resistant to inhibition with calcium channel blocking drugs such as verapamil and nifedipine. ${ }^{1314}$ There are few reports of calcium channel blocking drugs on contraction of human airway smooth muscle in vitro. The results of our study with verapamil are in agreement with those of previous studies, in which high concentrations $\left(10^{-6} \mathrm{~mol} / \mathrm{l}\right)$ of nifedipine and gallopamil (D600) were required to produce relatively small inhibition of contractions. ${ }^{1115}$ This is consistent with the hypothesis that $\mathrm{LTD}_{4}$ may rely principally in human airway smooth muscle, as it appears to in the guinea pig airway, ${ }^{13}$ on an intracellular source of activator $\mathrm{Ca}^{2+}$ to initiate contraction. In contrast, the inhibitory effect of verapamil on methacholine induced contractions in vitro suggests that a proportion of the contractile response to this agonist in human airway smooth muscle is dependent on influx of extracellular $\mathrm{Ca}^{2+}$ via calcium channels that are sensitive to inhibition by verapamil.

In contrast to our in vitro findings, in vivo verapamil significantly inhibited the bronchoconstriction induced by $\mathrm{LTD}_{4}$ though not by methacholine. The striking difference between the effects of verapamil on LTD $_{4}$ induced bronchoconstriction in vivo and in vitro and the selectivity of its effect on $\mathrm{LTD}_{4}$ in vivo 
suggests that verapamil is not acting solely on airway smooth muscle cells. Thus the airway response to $\mathrm{LTD}_{4}$ in man may be mediated both by a direct effect on airway smooth muscle and indirectly via a verapamil sensitive pathway.

There are several potential pathways by which $\mathrm{LTD}_{4}$ might indirectly cause bronchoconstriction. If $\mathrm{LTD}_{4}$ is capable of stimulating sensory nerve endings in the airway this could result in reflex vagal bronchoconstriction. In dogs with hyperreactive airways and in guinea pigs pretreatment with atropine prevents $\mathrm{LTD}_{4}$ induced bronchoconstriction. ${ }^{1617} \mathrm{Hol}-$ royde and Jackson, ${ }^{18}$ however, found that $\mathrm{LTD}_{4}$ had no effect on sensory irritant receptors in cats and dogs, although in cats it potentiated the response to serotonin by a vagal dependent mechanism. Thus the role of vagal pathways in the response to $\mathrm{LTD}_{4}$ in animals is unclear and in man untested. Furthermore, although neurotransmitter release is dependent on influx of extracellular $\mathrm{Ca}^{2+}$, this process is insensitive to inhibition by calcium channel blocking drugs. ${ }^{19}$

The slow onset of bronchoconstriction with $\mathrm{LTD}_{4}$ is consistent with release of secondary mediators as the mechanism of response. In guinea pigs intravenously administered leukotriene produces a reduction in dynamic compliance after pretreatment with a cyclo-oxygenase inhibitor, suggesting that some of the bronchoconstriction may be due to a generation of thromboxane $\mathrm{A}_{2} \cdot{ }^{20}$ Weiss et al, ${ }^{21}$ however, found that pretreatment with oral aspirin failed to attenuate the response to $\mathrm{LTD}_{4}$ in man.

$\mathrm{LTD}_{4}$ may increase airway permeability, and, since epithelial transport mechanisms require calcium, ${ }^{22}$ these could be susceptible to a blocking action of verapamil. Verapamil might reduce $\mathrm{LTD}_{4}$ induced changes in airway permeability and so affect access of $\mathrm{LTD}_{4}$ to smooth muscle receptors and reduce the effect of $\mathrm{LTD}_{4}$ in vivo.

In summary, our results suggest that in normal subjects $\mathrm{LTD}_{4}$ induced bronchoconstriction may result from a combination of direct and indirect mechanisms. The pathway mediating the indirect effect of $\mathrm{LTD}_{4}$ is at present unknown. Whether in asthmatic patients $\mathrm{LTD}_{4}$ acts by similar mechanisms requires to be established.

\section{References}

1 Orange RP, Austen KF. Slow reacting substance of anaphylaxis. Adv Immunol 1969;10:105-44.

2 Dahlen SE, Hedqvist P, Hammarstrom S, Samuelsson B. Leukotriene are potent constrictors of human bronchi. Nature 1980;229:484-6.

3 Barnes NC, Piper PJ, Costello JE. Comparitive effects of inhaled leukotriene $\mathrm{D}_{4}$ and histamine in normal human subjects. Thorax 1984;39:500-4.
4 Pong SS, De Haven RN. Characterization of a leukotriene $\mathrm{D}_{4}$ receptor in guinea pig lung. Proc Natl Acad Sci USA 1983;80:7415-9.

5 Lewis MA, Mong S, Verella RL, Hogaboom GK, Wu $\mathrm{H}-\mathrm{L}$, Crooke ST. Identification of specific binding sites for leukotriene $\mathrm{C}_{4}$ in human fetal lung. Prostaglandins 1984;27:961-74.

6 Triggle DJ. Calcium, the control of smooth muscle function and bronchial hyperactivity. Allergy 1983;38:1-9.

7 Rodger IW. Excitation-contraction coupling and uncoupling in airway smooth muscle. Br J Clin Pharmacol 1985;20:255S-264S.

8 Dubois AB, Botelho SY, Comroe JH. A new method for measuring airway resistance in man using a body plethysmograph: values in normal subjects and patients with respiratory disease. $J$ Clin Invest 1956;35:327-35.

9 Roberts JA, Raeburn D, Rodger IW, Thomson NC. Comparison of in vivo airway responsiveness and in vitro smooth muscle sensitivity to methacholine in man. Thorax 1984;39:837-43.

10 Roberts JA, Rodger IW, Thomson NC. Airway responsiveness to histamine in man: effect of atropine on in vivo and in vitro comparison. Thorax 1985;40:261-7.

11 Jones TR, Davis C, Daniels EE. Pharmacological study of the contractile activity of leukotriene $C_{4}$ and $D_{4}$ on isolated human airway smooth muscle. Can J Physiol Pharmacol 1982;60:638-43.

12 Rodger IW. Calcium ions and contraction of airway smooth muscle. In: Kay AB, ed. Asthma: clinical pharmacology and therapeutic progress. Oxford: Blackwell, Scientific Publications (in press).

13 Raeburn D, Rodger IW. Lack of effect of leukotriene $D_{4}$ on calcium uptake in airway smooth muscle. $\mathrm{Br} J$ Pharmacol 1984;83:499-504.

14 Foster RW, Okpalugo BL, Small RC. Antagonism of $\mathrm{Ca}^{2+}$ and other actions of verapamil on guinea pig isolated trachealis. Br J Pharmacol 1984;81:499-507.

15 Drazen JM, Fanta CH, Lacouture PG. Effect of Nifedipine on constriction of human tracheal strips in vitro. Br J Pharmacol 1983;78:687-91.

16 Hirschman CA, Davnell M, Brueyman T, Peters J. Airway constrictor effects of leukotriene $\mathrm{D}_{4}$ in dogs with hyper-reactive airways. Prostaglandins 1983;25:481-90.

17 Advenier C, Cerrina J, Duroux P, Floch A, Prudel J, Renier A. Sodium cromoglycate, verapamil and nicardipine antagonism to Leukotriene $\mathrm{D}_{4}$ bronchoconstriction. Br J Pharmacol 1983;78:301-6.

18 Holroyde MC, Jackson DM. Effect of leukotrienes (LTs) on pulmonary function and lung irritant receptors in cats and dogs. Br J Pharmacol 1983;78:C48.

19 Haeusler E. Differential effect of verapamil on excitation contraction coupling in smooth muscle and on excitation-secretion coupling in adrenergic nerve terminals. J Pharmacol Exp Ther 1972;180:672-82.

20 Weichman BM, Muccitelli RM, Osborn RR, Holden DA, Gleason JG, Wasserman MA. In vitro and in vivo mechanisms of leukotriene mediated bronchoconstriction in the guinea pig. $J$ Pharmacol Exp Ther 1982;222:202-8.

21 Weiss JW, Drazen JM, Coles N, et al. Airway constriction in normal humans produced by inhalation of LTD. JAMA 1983;249:2817-9.

22 Mavin MG, Estep JA, Zorn P. Effect of $\mathrm{Ca}^{2+}$ on sulphated mucous glycoprotein secretion in dog trachea. $J$ Appl Physiol 1982;52:198-205. 